\title{
Simulation of the mantle and crustal helium isotope signature in the Mediterranean Sea using a high-resolution regional circulation model
}

\author{
M. Ayache, J.-C. Dutay, P. Jean-Baptiste, and E. Fourré \\ Laboratoire des Sciences du Climat et de l'Environnement LSCE/IPSL, CEA-CNRS-UVSQ, Université Paris-Saclay, \\ 91191 Gif-sur-Yvette, France
}

Correspondence to: M Ayache (mohamed.ayache@1sce.ipsl.fr)

Received: 29 July 2015 - Published in Ocean Sci. Discuss.: 25 August 2015

Revised: 20 November 2015 - Accepted: 9 December 2015 - Published: 21 December 2015

\begin{abstract}
Helium isotopes $\left({ }^{3} \mathrm{He},{ }^{4} \mathrm{He}\right)$ are useful tracers for investigating the deep ocean circulation and for evaluating ocean general circulation models, because helium is a stable and conservative nuclide that does not take part in any chemical or biological process. Helium in the ocean originates from three different sources, namely, (i) gas dissolution in equilibrium with atmospheric helium, (ii) helium-3 addition by radioactive decay of tritium (called tritiugenic helium), and (iii) injection of terrigenic helium- 3 and helium- 4 by the submarine volcanic activity which occurs mainly at plate boundaries, and also addition of (mainly) helium-4 from the crust and sedimentary cover by $\alpha$-decay of uranium and thorium contained in various minerals.

We present the first simulation of the terrigenic helium isotope distribution in the whole Mediterranean Sea using a high-resolution model (NEMO-MED12). For this simulation we build a simple source function for terrigenic helium isotopes based on published estimates of terrestrial helium fluxes. We estimate a hydrothermal flux of $3.5 \mathrm{~mol}^{3}$

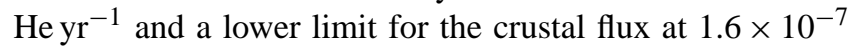
${ }^{4} \mathrm{He} \mathrm{mol} \mathrm{m}{ }^{-2} \mathrm{yr}^{-1}$.

In addition to providing constraints on helium isotope degassing fluxes in the Mediterranean, our simulations provide information on the ventilation of the deep Mediterranean waters which is useful for assessing NEMO-MED12 performance. This study is part of the work carried out to assess the robustness of the NEMO-MED12 model, which will be used to study the evolution of the climate and its effect on the biogeochemical cycles in the Mediterranean Sea, and to improve our ability to predict the future evolution of the
\end{abstract}

Mediterranean Sea under the increasing anthropogenic pressure.

\section{Introduction}

Helium isotopes are a powerful tool in Earth sciences. The ratio of ${ }^{3} \mathrm{He}$ to ${ }^{4} \mathrm{He}$ varies by more than 3 orders of magnitude in terrestrial samples. This results from the distinct origins of ${ }^{3} \mathrm{He}$ (essentially primordial) and ${ }^{4} \mathrm{He}$ (produced by the radioactive decay of uranium and thorium series) and their contrasting proportions in the Earth's reservoirs (Fig. 1). The atmospheric ratio, $R_{\text {air }}={ }^{3} \mathrm{He} /{ }^{4} \mathrm{He}=1.384 \times 10^{-6}$ (Clarke et al., 1976), can be considered constant due to the long residence time of helium, which is $\sim 10^{6}$ times longer than the mixing time of the atmosphere (based on the total helium content of the atmosphere and the global helium degassing flux estimated by Torgersen, 1989). Relative to this atmospheric ratio, typical ${ }^{3} \mathrm{He} /{ }^{4} \mathrm{He}$ ratios vary from $<0.1 R_{\text {air }}$ in the Earth's crust to an average of $8 \pm 1 R_{\text {air }}$ in the upper mantle, and up to some 40 to $50 R_{\text {air }}$ in products of plume-related ocean islands, such as Hawaii and Iceland (Ballentine and Burnard, 2002; Graham, 2002; Hilton et al., 2002).

At the ocean surface, helium is essentially in solubility equilibrium with the atmosphere. However, at depth, several important processes alter the isotopic ratio (Fig. 1 - see Schlosser and Winckler, 2002, for a review). Firstly, ${ }^{3} \mathrm{He}$ is produced by the radioactive decay of tritium (Jenkins and Clarke, 1976), and secondly, terrigenic helium is introduced not only by the release of helium from submarine volcanic activity at mid-ocean ridges and volcanic centres, with ele- 


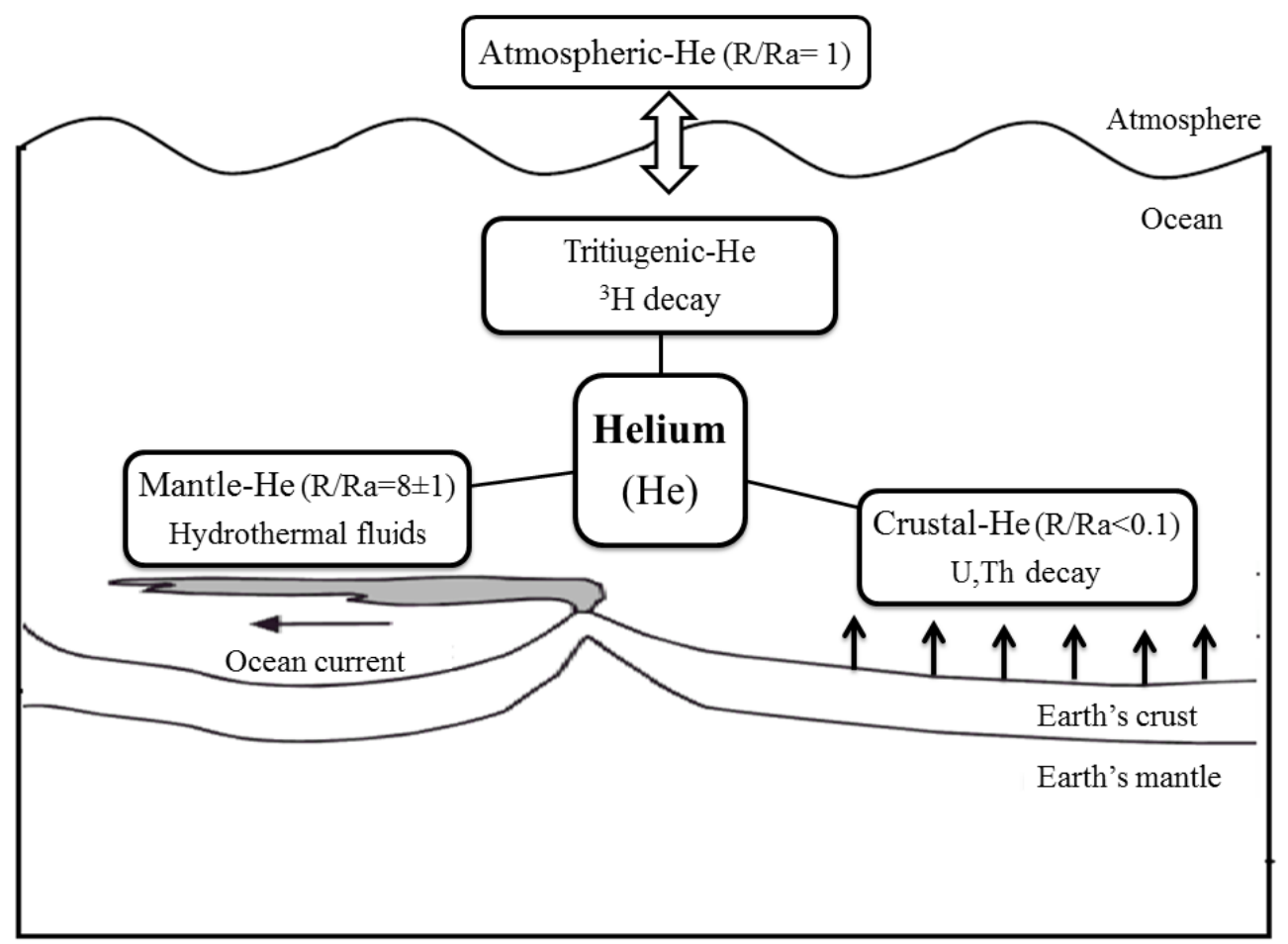

Figure 1. Schematic of helium components in the ocean. Note that the tritiugenic component consists of ${ }^{3} \mathrm{He}$ only. At the ocean surface, helium is essentially in solubility equilibrium with atmospheric He.

vated ${ }^{3} \mathrm{He} /{ }^{4} \mathrm{He}$ ratios typical of their mantle source (Lupton et al., 1977a, b; Jenkins et al., 1978; Lupton, 1979; Craig and Lupton, 1981; Jean-Baptiste et al., 1991a, 1992), but also by the addition of helium with a low ${ }^{3} \mathrm{He} /{ }^{4} \mathrm{He}$ ratio from the crust and sedimentary cover, mostly due to $\alpha$-decay of uranium and thorium minerals (Craig and Weiss, 1971).

Oceanic ${ }^{3} \mathrm{He} /{ }^{4} \mathrm{He}$ variations are usually expressed as $\delta^{3} \mathrm{He}$, the percentage deviation from the atmospheric ratio, defined as $\left(R_{\text {sample }} / R_{\text {air }}-1\right) \times 100$. Below the mixed layer, oceanic ${ }^{3} \mathrm{He} /{ }^{4} \mathrm{He}$ values are usually significantly higher than the atmospheric ratio, with $\delta^{3} \mathrm{He}$ up to $40 \%$ in the $\mathrm{Pa}$ cific Ocean (Craig and Lupton, 1981; Lupton, 1998). However, there are some exceptions. Intra-continental seas such as the Black Sea and the Mediterranean display deep-water ${ }^{3} \mathrm{He} /{ }^{4} \mathrm{He}$ ratios indicative of a preferential addition of ${ }^{4} \mathrm{He}$ rich crustal helium rather than ${ }^{3} \mathrm{He}$-rich mantle helium (Top and Clarke, 1983; Top et al., 1991; Roether et al., 1998, 2013).

Early investigations in the eastern Mediterranean (Meteor cruise M5/1987, Roether et al., 2013) have indeed revealed that deep waters have a crustal helium signature, with $\delta^{3} \mathrm{He}$ as low as $-5 \%$ (Fig. 2). Note that Fig. 2 shows that this deep core of crustal helium is being progressively erased by the addition of tritiugenic ${ }^{3} \mathrm{He}$ produced by the bomb tritium transient and by the recent dramatic changes in the thermohaline circulation of the eastern basin (EMed), known as the Eastern Mediterranean Transient (EMT) (Roether et al.,
1996, 2007, 2014), during which dense waters of Aegean origin replaced the Adriatic source of the deep waters in the EMed.

Deconvolution of the various helium components using neon indicates that the mantle helium contribution is only $\sim 5 \%$ (Roether et al., 1998). In the Mediterranean Sea, terrigenic helium is therefore largely of crustal origin due to the presence of a continental-type crust and a high sediment load of continental origin, but also because mantle helium, which is produced by the submarine volcanic activity in only a few places in the Mediterranean Sea (Aeolian Arc, Aegean Arc, and Pantelleria Rift in particular), is released at rather shallow depths (Dando et al., 1999) and is therefore quickly transferred to the atmosphere.

Mantle ${ }^{3} \mathrm{He}$ was discovered in the deep ocean by Clarke et al. (1970). It is injected at mid-ocean ridges as part of the processes generating new oceanic crusts and advected by ocean currents. Since this discovery, helium isotopes have been used extensively to trace the deep ocean circulation (Jamous et al., 1992; Jean-Baptiste et al., 1991b, 1997, 2004; Lupton, 1996, 1998; Top et al., 1991; Rüth et al., 2000; Well et al., 2001; Srinivasan et al., 2004) and in conjunction with tritium have been used to study ocean circulation, ventilation and mixing processes (Andrie and Merlivat, 1988; Jenkins, 1977, 1988; Schlosser et al., 1991; Roether et al., 2013). Ventilation is defined as the process of moving a parcel of water from the surface to a given subsurface location. It can oc- 

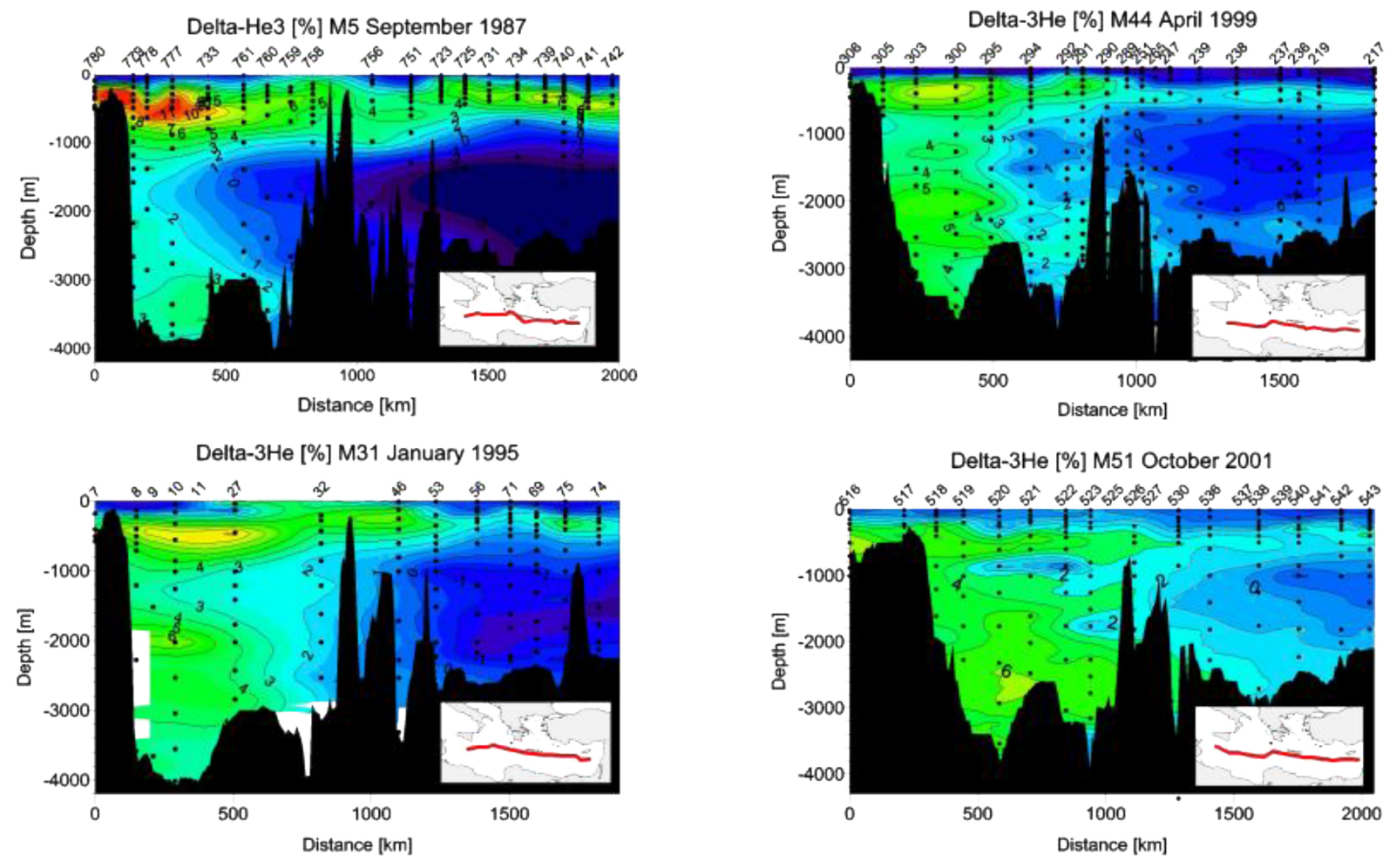

$11098165 \times 32 \times 0 ; 23 \%$

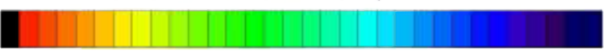

Figure 2. $\delta^{3} \mathrm{He}$ sections of the Meteor cruises in 1987, 1995, 1999 and 2001. Numbers on top are station numbers, observations are indicated by dots, and the actual sections are shown in the inset maps. Isolines are by objective mapping (reproduced from Roether et al., 2013).

cur through convection, subduction, advection, and diffusion (Goodman, 1998; England, 1995).

The helium isotope distribution in the deep oceans has also been simulated by various ocean circulation models to constrain global helium degassing fluxes and evaluate the degree to which models can correctly reproduce the main features of the world's ocean circulation (Farley et al., 1995; Dutay et al., 2002, 2010; Bianchi et al., 2010).

In this study we build a source function for the release of terrigenic helium components (crust and mantle) into the deep Mediterranean and apply it to a high-resolution oceanic model of the Mediterranean Sea. The simulated heliumisotope distribution is then compared with available data to constrain terrigenic helium fluxes. In addition to providing constraints on the degassing flux, our work is the first attempt to simulate natural helium-3 in a high-resolution regional model of the Mediterranean Sea, and provides new information on the model's capacity to represent the ventilation of deep waters.

\section{Description of the model}

The model used in this work is the NEMO (Nucleus for European Modelling of the Ocean) free surface ocean general circulation model (Madec and NEMO-Team., 2008) in a regional configuration called NEMO-MED12 (Beuvier et al., 2012a).

This model of the Mediterranean Sea has been used previously to study anthropogenic tritium and its decay product helium-3 (Ayache et al., 2015), the anthropogenic carbon uptake (Palmiéri et al., 2015), the transport through the Strait of Gibraltar (Soto-Navarro et al., 2014), as well as the Western Mediterranean Deep Water (WMDW) formation (Beuvier et al., 2012a) and the mixed-layer response under high-resolution air-sea forcings (Lebeaupin Brossier et al., 2011). This model satisfactorily simulates the main structures of the thermohaline circulation of the Mediterranean Sea, with mechanisms having a realistic timescale compared to observations. In particular, tritium/helium-3 simulations (Ayache et al., 2015) have shown that the EMT signal from the Aegean sub-basin is realistically simulated, with its corresponding penetration of tracers into the deep water in early 1995. The strong convection event of winter 2005 and the 
following years in the Gulf of Lion was satisfactorily captured as well. However, some aspects of the model still need to be improved: in the eastern basin, tritium/helium-3 simulations have highlighted the too-weak formation of Adriatic Deep Water (AdDW), followed by a weak contribution to the Eastern Mediterranean Deep Water (EMDW) in the Ionian sub-basin. In the western basin, the production of WMDW is correct, but the spreading of the recently ventilated deep water to the south of the basin is too weak. The consequences of these weaknesses in the model's skill in simulating some important aspects of the dynamics of the deep ventilation of the Mediterranean will have to be kept in mind when analysing these helium simulations.

NEMO-MED12 covers the whole Mediterranean Sea, but also extends into the Atlantic Ocean. Horizontal resolution is one-twelfth of a degree, thus varying with latitude between 8 and 6.5 and $8 \mathrm{~km}$ from 30 to $46^{\circ} \mathrm{N}$, respectively, and between 5.5 and $7.5 \mathrm{~km}$ in longitude. Vertical resolution varies with depth, from $1 \mathrm{~m}$ at the surface to $450 \mathrm{~m}$ at the bottom (50 levels in total). We use partial steps to adjust the last numerical level with the bathymetry. The exchanges with the Atlantic Ocean are performed through a buffer zone from 11 to $7.5^{\circ} \mathrm{W}$, where 3-D temperature and salinity model fields are relaxed to the observed climatology (Beuvier et al., 2012a).

NEMO-MED12 is forced at the surface by ARPERA (Herrmann and Somot, 2008; Herrmann et al., 2010) daily fields of the momentum, evaporation and heat fluxes over the period 1958-2013. For the sea-surface temperature (SST), a relaxation term is applied to the heat flux (Beuvier et al., 2012a). The total volume of water in the Mediterranean Sea is conserved by restoring the sea-surface height ( $\mathrm{SSH}$ ) in the Atlantic buffer zone toward the GLORYS1 reanalysis (Ferry et al., 2010).

The initial conditions (temperature, salinity) for the Mediterranean Sea are prescribed from the MedAtlas-II (MEDAR-MedAtlas-group, 2002; Rixen et al., 2005) climatology weighted by a low-pass filter with a time window of 10 years using the MedAtlas data covering the 1955-1965 period, following Beuvier et al. (2012a). For the Atlantic buffer zone, the initial state is set from the 2005 World Ocean Atlas for temperature (Locarnini et al., 2006) and salinity (Antonov et al., 2006). River runoff is prescribed from the interannual data set of Ludwig et al. (2009) and Vörösmarty et al. (1996).

Full details of the model and its parameterizations are described by Beuvier et al. (2012a, b), Palmiéri et al. (2015) and Ayache et al. (2015).

\section{The tracer model}

Helium is implemented in the model as a passive conservative tracer which does not affect ocean circulation. It is transported in the Mediterranean Sea by NEMO-MED12 physical fields using an advection-diffusion equation (Eq. 1). The rate of change of the concentration of each specific passive tracer $\mathrm{C}$ is

$\frac{\delta C}{\delta t}=S(C)-U \cdot \nabla C+\nabla \cdot(K \nabla C)$,

where $S(C)$ is the tracer source (at the seafloor) and sink (at the air-sea interface); $U \nabla C$ is advection of the tracer along the three perpendicular axes and $\nabla(K \nabla C)$ is the lateral and vertical diffusion, with the same parameterization as for the hydrographic tracers.

Because ${ }^{3} \mathrm{He}$ and ${ }^{4} \mathrm{He}$ are passive tracers, simulations could be run in a computationally efficient off-line mode. This method relies on previously computed circulation fields $(\mathrm{U}, \mathrm{V}, \mathrm{W})$ from the NEMO-MED12 dynamical model (Beuvier et al., 2012a). Physical forcing fields are read daily and interpolated to give values for each $20 \mathrm{~min}$ time step. The same approach was used by Ayache et al. (2015) to model the anthropogenic tritium invasion and by Palmiéri et al. (2015) to simulate CFCs and anthropogenic carbon. This choice is justified by the fact that these tracers are passive. Their injection does not alter the dynamics of the ocean, and they have no influence on the physical properties of water, unlike hydrographic tracers such as temperature or salinity.

The simulations were initialized with uniform ${ }^{3} \mathrm{He}$ and ${ }^{4} \mathrm{He}$ concentrations corresponding to those at solubility equilibrium with the partial pressures of these isotopes in the atmosphere, for seawater at $T=10^{\circ} \mathrm{C}$ and $S=34$ (Weiss, 1971). Model simulations were integrated for 500 years until they reached a quasi-steady state; that is, the globally averaged drift was less than $10^{-2} \delta^{3} \mathrm{He} \%$ per 200 years of run.

\subsection{Parameterization of the helium injection}

Terrigenic helium in the Mediterranean Sea has two components: (1) crustal helium, originating from the crust and overlying sediment cover, and (2) mantle helium, injected by submarine volcanic activity. For the injection of helium, we follow the protocol proposed by Dutay et al. $(2002,2004)$ and Farley et al. (1995). Each component has a characteristic ${ }^{3} \mathrm{He} /{ }^{4} \mathrm{He}$ value. The anthropogenic ${ }^{3} \mathrm{He}$ distribution due to the decay of bomb tritium has already been addressed by Ayache et al. (2015).

For this study, we ran two separate simulations, one for each helium component. Each simulation has two boundary conditions: a loss term at the surface, due to the sea-to-air gas exchange, and a source term at the seafloor, describing terrigenic tracer input. Each simulation thus represents the sum of the specified terrigenic component and the atmospheric component, with the distributions of ${ }^{3} \mathrm{He}$ and ${ }^{4} \mathrm{He}$ computed separately. We then calculate the isotopic ratio using the $\delta^{3} \mathrm{He}$ notation.

\subsubsection{Surface boundary condition}

The only sink for oceanic helium is loss to the atmosphere. At the air-sea interface, the model will exchange ${ }^{3} \mathrm{He}$ and 
${ }^{4} \mathrm{He}$ with the atmosphere using sea-air flux boundary conditions that are analogous to those developed for helium during the second phase of OCMIP http://ocmip5.ipsl.jussieu.fr/ OCMIP/phase2/simulations/Helium/HOWTO-Helium.html (Dutay et al., 2002). Using the standard flux-gradient formulation for a passive gaseous tracer, the flux of helium $F_{\mathrm{He}}$ is given by

$F_{\mathrm{He}}=K_{\mathrm{w}}\left(C_{\mathrm{eq}}-C_{\text {surf }}\right)$,

where $K_{\mathrm{W}}$ is the gas transfer (piston) velocity $\left(\mathrm{m} \mathrm{s}^{-1}\right), C_{\text {surf }}$ is the modelled surface ocean concentration of ${ }^{3} \mathrm{He}$ or ${ }^{4} \mathrm{He}$ as appropriate, and $C_{\mathrm{eq}}$ is the atmospheric solubility equilibrium concentration (Weiss, 1971) at the local sea-surface temperature (SST) and salinity (SSS).

Here, we neglect spatio-temporal variations in atmospheric pressure and assume it remains at $1 \mathrm{~atm}$. The gas transfer velocity is computed from surface-level wind speeds, $u\left(\mathrm{~m} \mathrm{~s}^{-1}\right)$, from the ARPERA forcing (Herrmann and Somot, 2008; Herrmann et al., 2010) following the Wanninkhof (1992) (Eq. 3) formulation

$K_{\mathrm{W}}=a u^{2}(S c / 660)^{1 / 2}$,

where $a=0.31$ and $S c$ is the Schmidt number which is to be computed from the modelled SST, using the formulation for ${ }^{4}$ He given by Wanninkhof (1992), derived from Jähne et al. (1987a). For ${ }^{3} \mathrm{He}$, we reduce the Schmidt number (relative to $\left.{ }^{4} \mathrm{He}\right)$ by $15 \%\left(S c_{\mathrm{He}-3}=S c_{\mathrm{He}-4} / 1.15\right)$ based on the ratio of the reduced masses, which is consistent with helium isotopic fractionation measurements by Jähne et al. (1987b). Therefore, in the following, the modelled atmospheric component is the helium distribution at equilibrium with surface airsea boundary conditions, without any helium flux from the seafloor.

\subsubsection{Crustal helium fluxes}

Lake and groundwater studies have shown that radiogenic helium is continuously released from the underlying crustal bedrock (see Kipfer et al., 2002, for a review). Porewaters trapped in oceanic sediments are also enriched in radiogenic ${ }^{4} \mathrm{He}$ from the underlying oceanic crust and in situ ${ }^{4} \mathrm{He}$ production by uranium- and thorium-rich minerals, releasing their helium at the sea bottom (Sano and Wakita, 1985; Sano et al., 1987; Chaduteau et al., 2009). Deep waters of intracontinental seas such as the Mediterranean are more prone to exhibiting a radiogenic ${ }^{4} \mathrm{He}$ signature than the open ocean because the continental upper crust is about 40 times more enriched in uranium and thorium than the oceanic crust (Taylor and McLennan, 1985; Torgersen, 1989).

In the deep eastern Mediterranean, southwest of Crete, extremely high radiogenic ${ }^{4} \mathrm{He}$ concentrations have indeed been measured in deep brine pools created by the advection of deep buried fluids hosted by the sedimentary matrix beneath the Messinian evaporites (Winckler et al., 1997; Charlou et al., 2003). However, there are no data on the spatial variability of the crustal helium injection into deep waters. Therefore, in the model, crustal helium is injected as a uniform flux (in mol of helium per square metre of seafloor $>1000 \mathrm{~m}$ ) with a ${ }^{3} \mathrm{He} /{ }^{4} \mathrm{He}$ ratio of $0.06 R_{\text {air }}$ (Winckler et al., 1997; Charlou et al., 2003). The initial value of this flux is that estimated by Roether et al. (1998) (Table 2) using a multi-box model in which the thermohaline circulation of the eastern Mediterranean is represented by a deep reservoir (> $1000 \mathrm{~m}$ depth) and two intermediate water cells (Roether et al., 1994) (see Table 2). Sensitivity tests were made to determine the flux which produces the best agreement with available data (Roether et al., 1998, 2013).

\subsubsection{Mantle helium fluxes}

The subduction of the African plate below Europe is responsible for the volcanic activity which takes place in the Mediterranean basin (Fig. 3). The main submarine activity is found in the Tyrrhenian and Aegean seas, and in the Sicily Channel (Dando et al., 1999).

Hydrothermal vents in the Tyrrhenian sub-basin are found all along the Aeolian volcanic arc (Fig. 3) from Palinuro in the north to Eolo and Enarete in the southwest (Lupton et al., 2011), as well as on the Marsili seamount (Lupton et al., 2011).

In the Aegean, hydrothermal systems occur along the southern Aegean volcanic arc from Sousaka and Methana in the west to Kos, Yali and Nisiros in the east (Dando et al., 1999).

Finally, a recent helium isotope survey across the Sicily Channel, which separates the Sicilian platform from Africa, also suggests hydrothermal helium input between 600 and $1000 \mathrm{~m}$ depth associated with the Pantelleria Rift (Fourré and Jean-Baptiste, unpublished results).

Location and depth of the active zones are shown in Fig. 3. Table 1 summarizes the ${ }^{3} \mathrm{He}$ fluxes used for our simulations. For the Aeolian and Aegean volcanic arcs, ${ }^{3} \mathrm{He}$ fluxes were determined by simple scaling to the global ${ }^{3} \mathrm{He}$ flux from arc volcanism, which can be estimated (to within a factor of 2) to be $\sim 4 \times 10^{-3} \mathrm{~mol}$ of ${ }^{3} \mathrm{He}$ per kilometre of arc based on the assumption that the magma production rate of arcs is $\sim 20 \%$ of that of mid-ocean ridges (Torgersen, 1989; Hilton et al., 2002) and the total length of subduction zones. For the Marsili seamount, the ${ }^{3} \mathrm{He}$ flux was estimated from ${ }^{3} \mathrm{He}$ fluxes at nearby subaerial volcanoes (Allard, 1992a, b). ${ }^{3} \mathrm{He} /{ }^{4} \mathrm{He}$ isotopic ratios were chosen according to available in situ data (when available) or to ${ }^{3} \mathrm{He} /{ }^{4} \mathrm{He}$ data from nearby subaerial volcanoes.

\section{Observations used for the comparison with model results}

The tracer data in the Mediterranean which are relevant for comparison with model results are the Meteor cruises across 


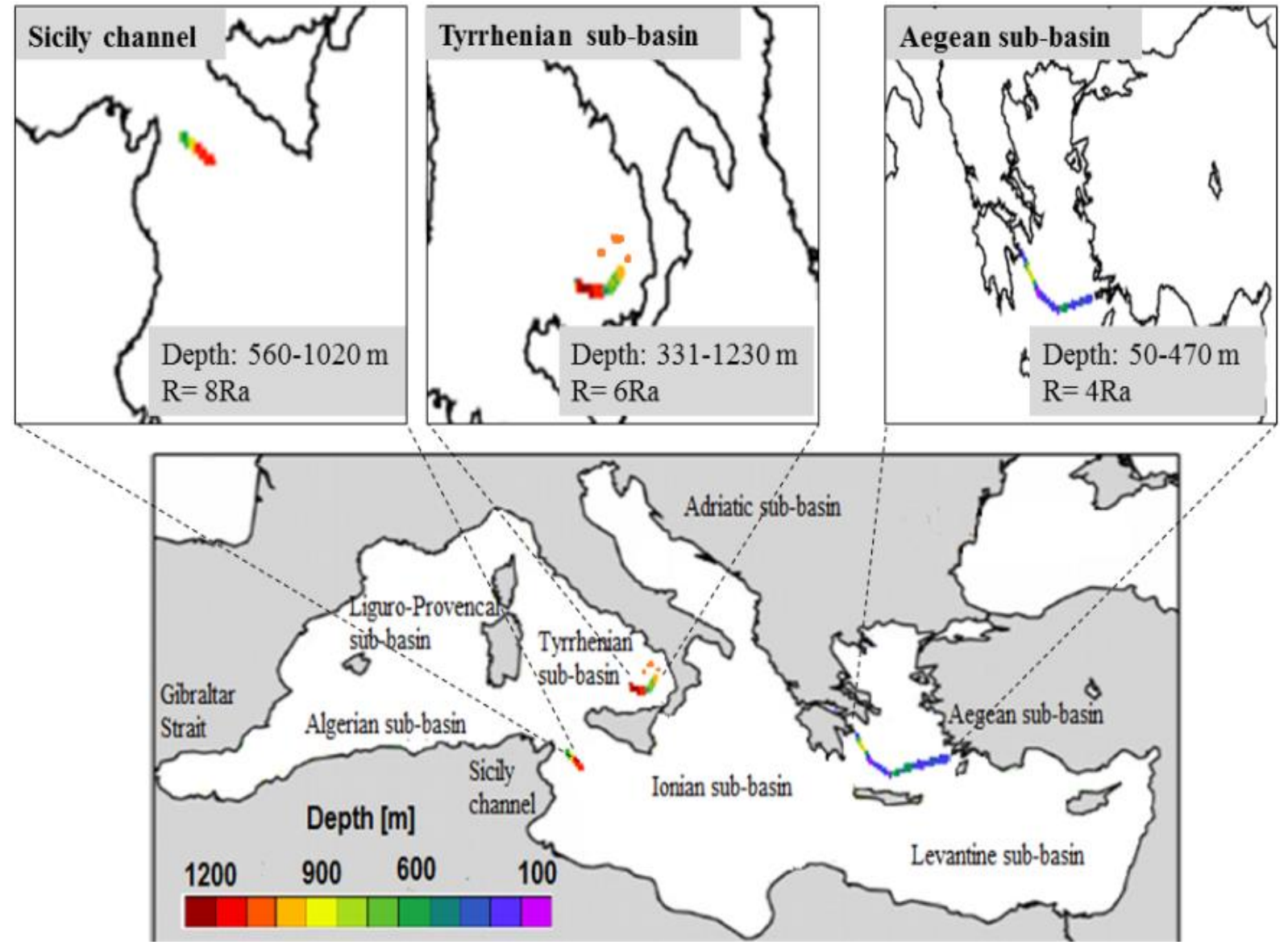

Figure 3. Depth (in metres) and localization of mantle helium injection in the Mediterranean Sea.

Table 1. Release rates of mantle helium in the Mediterranean Sea used in the model (see Sect. 3.1.3).

\begin{tabular}{|c|c|c|c|}
\hline Region & Prescribed ${ }^{3}$ He Flux & ${ }^{3} \mathrm{He} /{ }^{4} \mathrm{He}$ & References \\
\hline $\begin{array}{l}\text { Tyrrhenian basin: } \\
\text { Aeolian Arc }\end{array}$ & $0.8\left(\mathrm{~mol} \mathrm{yr}^{-1}\right)$ & $6 \mathrm{Ra}$ & $\begin{array}{l}\text { Sano et al. (1989), Tedesco et al. (1995), } \\
\text { Tedesco and Scarsi (1999), Capasso et al. (2005), } \\
\text { Capaccioni et al. (2007), Martelli et al. (2008), } \\
\text { Fourré et al. (2012) }\end{array}$ \\
\hline Marsili seamount & $0.4\left(\mathrm{~mol} \mathrm{yr}^{-1}\right)$ & & \\
\hline $\begin{array}{l}\text { Aegean basin: } \\
\text { South Aegean Arc }\end{array}$ & $1.5\left(\mathrm{~mol} \mathrm{yr}^{-1}\right)$ & $4 \mathrm{Ra}$ & $\begin{array}{l}\text { Fiebig et al. (2004), Shimizu et al. (2005), } \\
\text { D'Alessandro et al. (1997) }\end{array}$ \\
\hline $\begin{array}{l}\text { Sicily Channel: } \\
\text { Pantelleria Rift }\end{array}$ & $0.8\left(\mathrm{~mol} \mathrm{yr}^{-1}\right)$ & $8 \mathrm{Ra}$ & Parello et al. (2000) \\
\hline
\end{tabular}

the eastern Mediterranean basin (Roether et al., 2013; see Fig. 2) and the helium isotope survey carried out by Lupton et al. (2011) in the Tyrrhenian Sea. Additional $\delta^{3} \mathrm{He}$ data (Fourré and Jean-Baptiste, unpublished data) from the November 2013 Record cruise in the Sicily Channel (Geotraces program) are also available. The 1987 Meteor sec- tion is of particular interest since it is the less affected by tritiugenic ${ }^{3} \mathrm{He}$ (Fig. 2) and therefore the deconvolution of the various helium components using neon is the most accurate. This deconvolution is carried out using the method proposed by Roether et al. (1998, 2001), which allows one to derive the atmospheric helium component from the neon dis- 
Table 2. Release rate of crustal helium used in the model and comparison with crustal helium fluxes in various geological settings.

\begin{tabular}{llll}
\hline Region & ${ }^{3} \mathrm{He}\left(\mathrm{mol} \mathrm{m}^{-2} \mathrm{yr}^{-1}\right)$ & ${ }^{4} \mathrm{He}\left(\mathrm{mol} \mathrm{m}^{-2} \mathrm{yr}^{-1}\right)$ & References \\
\hline Mediterranean Sea & $1.32 \times 10^{-14}$ & $1.6 \times 10^{-7}$ & This work \\
Continental crust & $4.7 \times 10^{-14}$ & $1.4 \times 10^{-6}$ & Torgersen (1989) \\
Continental crust & - & $2.2 \times 10^{-6}$ & Torgersen (2010) \\
Eastern Med. & - & $1.6 \times 10^{-6}$ & Roether et al. (1998) \\
Black Sea & $5.8 \times 10^{-13}$ & $0.7 \times 10^{-6}$ & Top and Clarke (1983) \\
Global Ocean floor & $(1.5-4.6) \times 10^{-15}$ & $(0.2-1.4) \times 10^{-7}$ & Torgersen (1989) \\
Pacific Ocean & - & $(0.01-0.2) \times 10^{-7}$ & Sano et al. (1987) \\
Pacific Ocean & - & $0.75 \times 10^{-7}$ & Well et al. (2001) \\
\hline
\end{tabular}

tribution and then to obtain the terrigenic ${ }^{4} \mathrm{He}$ component by substracting this atmospheric component from the total measured helium concentration. The atmospheric and terrigenic ${ }^{3} \mathrm{He}$ components are then obtained using the ${ }^{3} \mathrm{He} /{ }^{4} \mathrm{He}$ ratios of dissolved atmospheric and terrigenic helium, respectively. For the Tyrrhenian Sea, the $\delta^{3} \mathrm{He}$ excess due to hydrothermal activity along the Aeolian arc is obtained by substracting the background vertical $\delta^{3} \mathrm{He}$ profile of vertical cast V01 (see Lupton et al., 2011) from the measured $\delta^{3} \mathrm{He}$. The same method was used for Sicily Channel data. Accuracy of the deconvoluted $\delta^{3} \mathrm{He}$ is in the range $1-1.5 \%$.

\section{Results}

\subsection{Crustal helium distribution}

We begin our analysis by providing an overview of the simulated crustal + atmospheric helium component. Figure $4 \mathrm{a}$ displays a section of modelled $\delta^{3} \mathrm{He}_{\text {crust+atm }}$ along a W$\mathrm{E}$ transect across the EMed. As expected, the $\delta^{3} \mathrm{He}_{\text {crust+atm }}$ distribution exhibits negative values, predominately in the deep waters, hinting at the presence of crustal He highly enriched in radiogenic ${ }^{4} \mathrm{He}$. The model correctly simulates the crustal-He distribution in the Levantine sub-basin (Fig. 4c), where the simulated $\delta^{3} \mathrm{He}_{\text {crust+atm }}$ values agree reasonably well with observations from Meteor cruise M5. However,

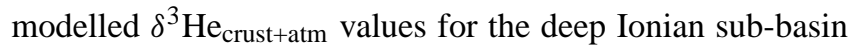
are too low, with a mean value below $3500 \mathrm{~m}$ around $-7 \%$ compared to $-4.5 \pm 0.7 \%$ in the data (Fig. $4 \mathrm{~d}$ ). This too large an accumulation of crustal ${ }^{4} \mathrm{He}$ is the expected consequence of the too low ventilation of the deep Ionian subbasin in the model, as already diagnosed in the anthropogenic tritium $/{ }^{3} \mathrm{He}$ simulations of (Ayache et al., 2015). The model generates too weak a formation of Adriatic Deep Water (AdDW) that prevents the model from reproducing the observed signal associated with injection at depth of surface water.

The simulated $\delta^{3} \mathrm{He}_{\text {crust+atm }}$ distribution in the western basin (Fig. 4b) shows the same gradient as in the Levantine basin, with negative values in the deep water (values around $-5.5 \%$ ) as a result of the homogenous crustal-He flux over the whole basin (see Sect. 3). In the surface layer helium in solution is essentially in equilibrium with atmospheric he-

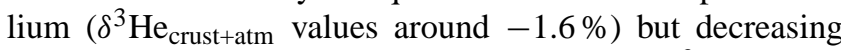
steadily with depth down to a layer of minimum $\delta^{3} \mathrm{He}_{\text {crust+atm }}$ values in deep waters. Although the terrigenic component cannot been estimated quantitatively for the WMed because of the lack of a precise value for its ${ }^{3} \mathrm{He} /{ }^{4} \mathrm{He}$ ratio $\left(R_{\mathrm{ter}}\right)$, the lower limit of $\delta^{3} \mathrm{He}_{\text {crust+atm }}$ (taking $R_{\text {ter }}$ equal to zero) is in the range -3.5 to $-4.5 \%$ for deep waters. This is less radiogenic than in the eastern basin, in agreement with the conclusions of Rhein et al. (1999) that the crustal component may be small in the WMed. Our model results $(-5.5 \%$ on average) are somewhat lower, suggesting that, as already observed in the eastern basin, the model probably underestimates the ventilation rate of deep waters in the western basin too.

\subsection{Mantle helium distribution}

As discussed above, the main active submarine volcanic systems are located in the Tyrrhenian and Aegean seas and in the Sicily Channel (Fig. 3).

\subsubsection{Pantelleria Rift}

In the Pantelleria Rift, a clearly visible plume of mantle helium is simulated between 500 and $1000 \mathrm{~m}$ depth (Fig. 5a).

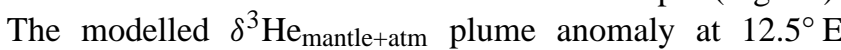
reaches a maximum value of $2.5 \%$ above the atmospheric background of $-1.6 \%$. This value is in good agreement with in situ observations at the same location $(2.3 \%$ above background at $800 \mathrm{~m}$, Fig. 5d; Fourré and Jean-Baptiste, unpublished data).

\subsubsection{Tyrrhenian Sea}

The submarine volcanic activity in the Tyrrhenian is essentially confined to depths less than $1200 \mathrm{~m}$. The corresponding mantle helium input creates a weak but welldefined $\delta^{3} \mathrm{He}_{\text {mantle+atm plume (Fig. 5b) centred around }}$ $1000 \mathrm{~m}$ depth, which propagates into the entire Tyrrhenian sub-basin (Fig. 6). Average simulated $\delta^{3} \mathrm{He}_{\text {mantle+atm }}$ 

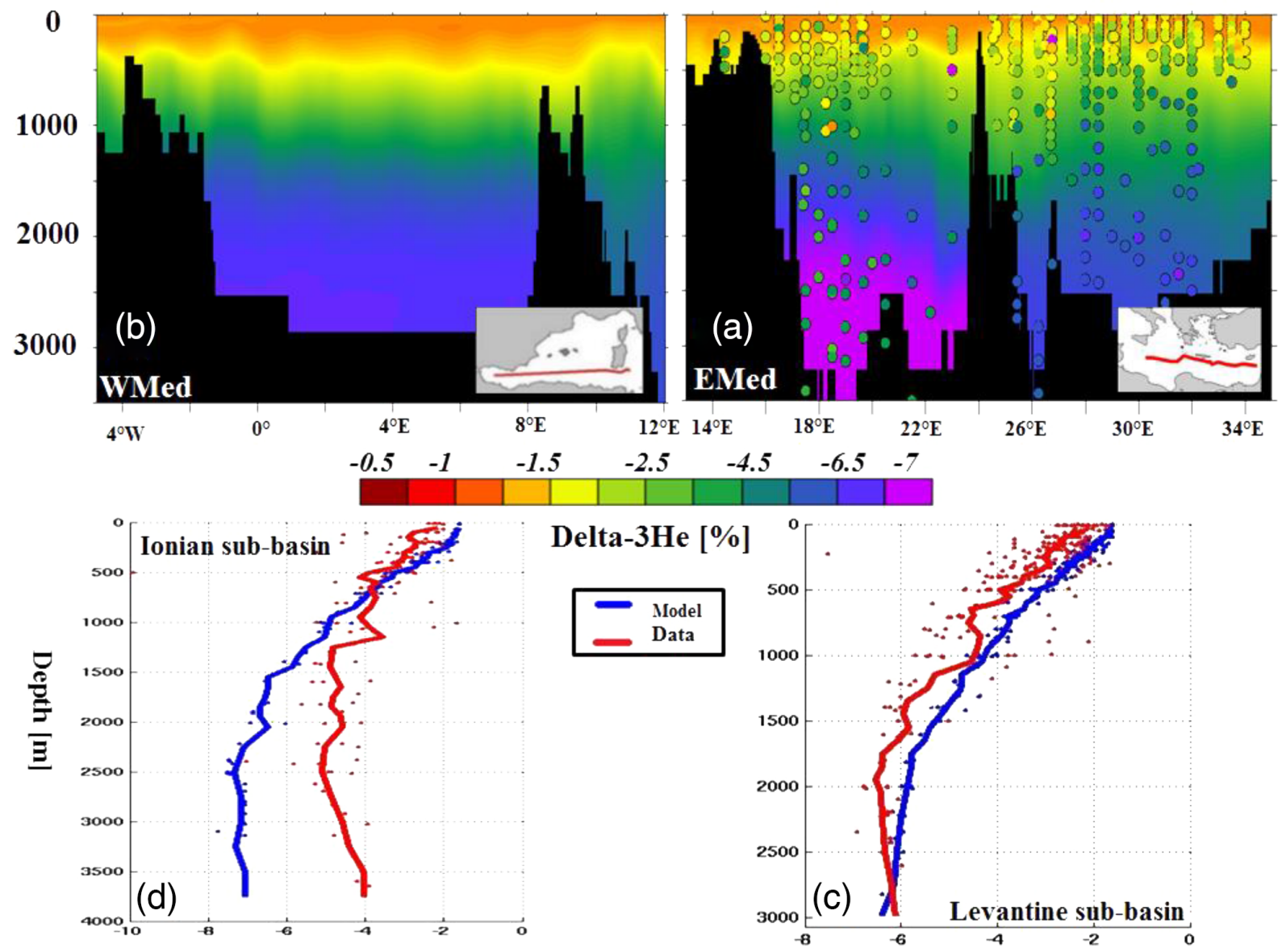

Figure 4. Crustal+atmospheric $\delta^{3} \mathrm{He}$ (in \%) model-data comparison along the Meteor M5 (September 1987) section: (a) Colour-filled contours indicate simulated $\delta^{3} \mathrm{He}(\%)$, whereas colour-filled dots represent the crustal + atmospheric $\delta^{3} \mathrm{He}$ deduced from in situ observations using the component separation method of Roether et al. (1998) in the eastern basin (see Sect. 4 for details). (b): same as (a), but in the western basin (WMed). There are no quantitative data for comparison in the WMed. (c) and (d): comparison of average vertical profiles along the Meteor M5/9-1987 section for the Levantine and Ionian sub-basins, respectively; model results are in blue; red indicates the in situ data.

values above the atmospheric background $(-1.6 \%)$ are within $\delta^{3} \mathrm{He}_{\text {mantle+atm }}=-0.5 \%$ of the corresponding abovebackground $\delta^{3} \mathrm{He}$ measurements of Lupton et al. (2011) in the same area (Fig. 5b and e).

\subsubsection{Aegean Sea}

Hydrothermal venting in the Aegean sub-basin occurs at shallow depths (between 50 and $450 \mathrm{~m}$ depth) compared to the two other sites in the Mediterranean Sea; in consequence the simulated $\delta^{3} \mathrm{He}_{\text {mantle+atm anomaly is particularly weak in }}$ this area due to the rapid helium degassing into the atmosphere (Fig. 5c) and the signal does not propagate into the larger area around the Aegean Sea (Fig. 6). Note that no $\delta^{3} \mathrm{He}$ data are available for comparison in the Aegean basin.

Figure 6 provides a descriptive view of the global distribution of the modelled $\delta^{3} \mathrm{He}_{\text {mantle+atm }}$ signal over the Mediterranean Sea. The figure highlights the location of mantle-
He sources, and of their propagation through the interior of the Mediterranean Sea. The $\delta^{3} \mathrm{He}_{\text {mantle+atm anomaly is }}$ clearly visible over the three main areas of submarine volcanic activity. The mantle-He plume injected by the Aeolian Arc spreads over the entire Tyrrhenian sub-basin, then leaves through the Corsican Channel $(1900 \mathrm{~m})$ and extends into the Liguro-Provencal sub-basin associated with the Levantine Intermediate Water (LIW) trajectory, and into the Algerian sub-basin through the Sardinian Channel. The input from the Pantelleria Rift is topographically trapped in the $\mathrm{Si}$ cilian Channel. The Aegean sub-basin is also impacted by the mantle $\mathrm{He}$ : the He excess is localized in the western part of this sub-basin between mainland Greece and the island of Crete. 

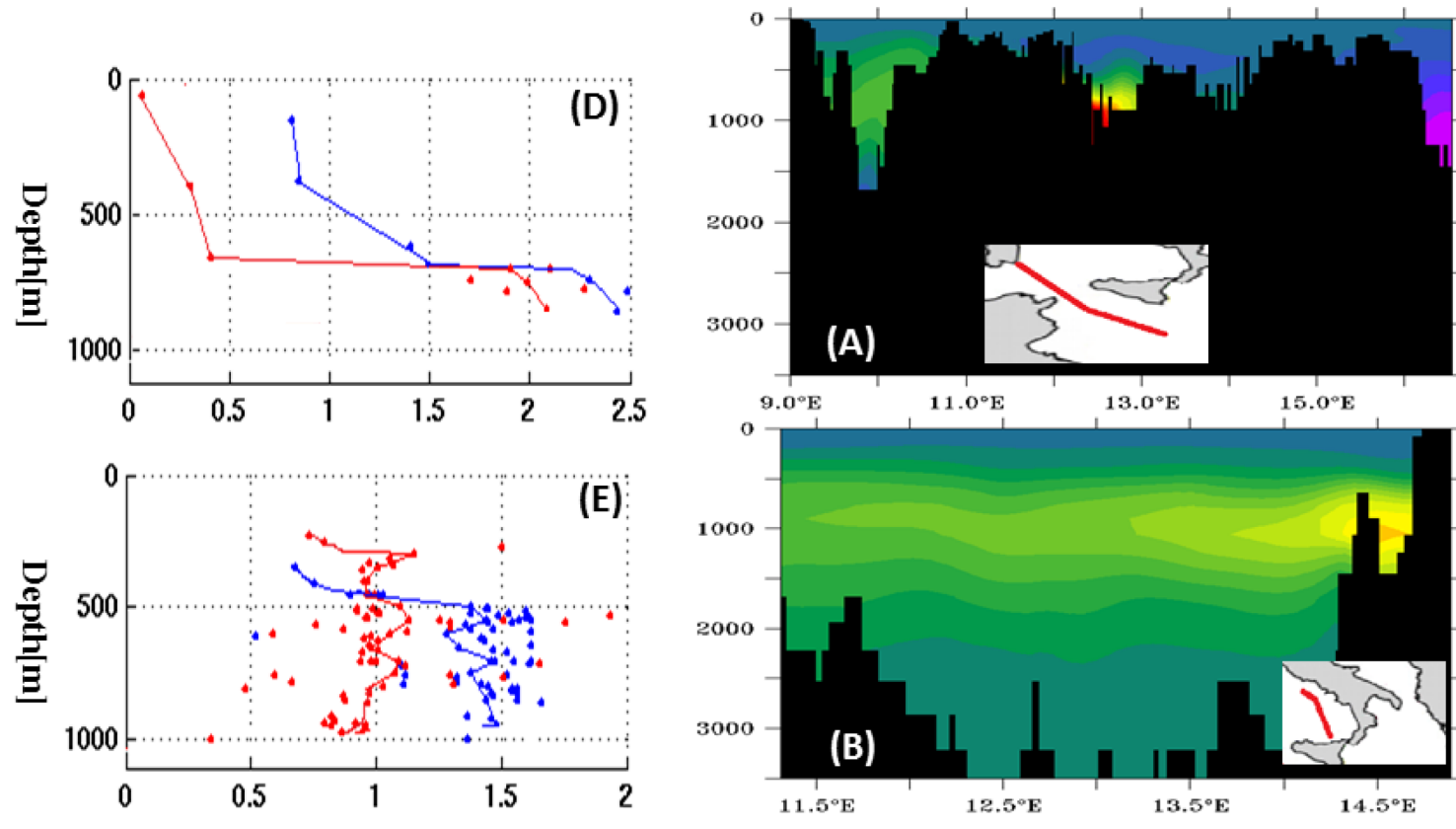

Delta $-{ }^{3} \mathrm{He}[\%]$
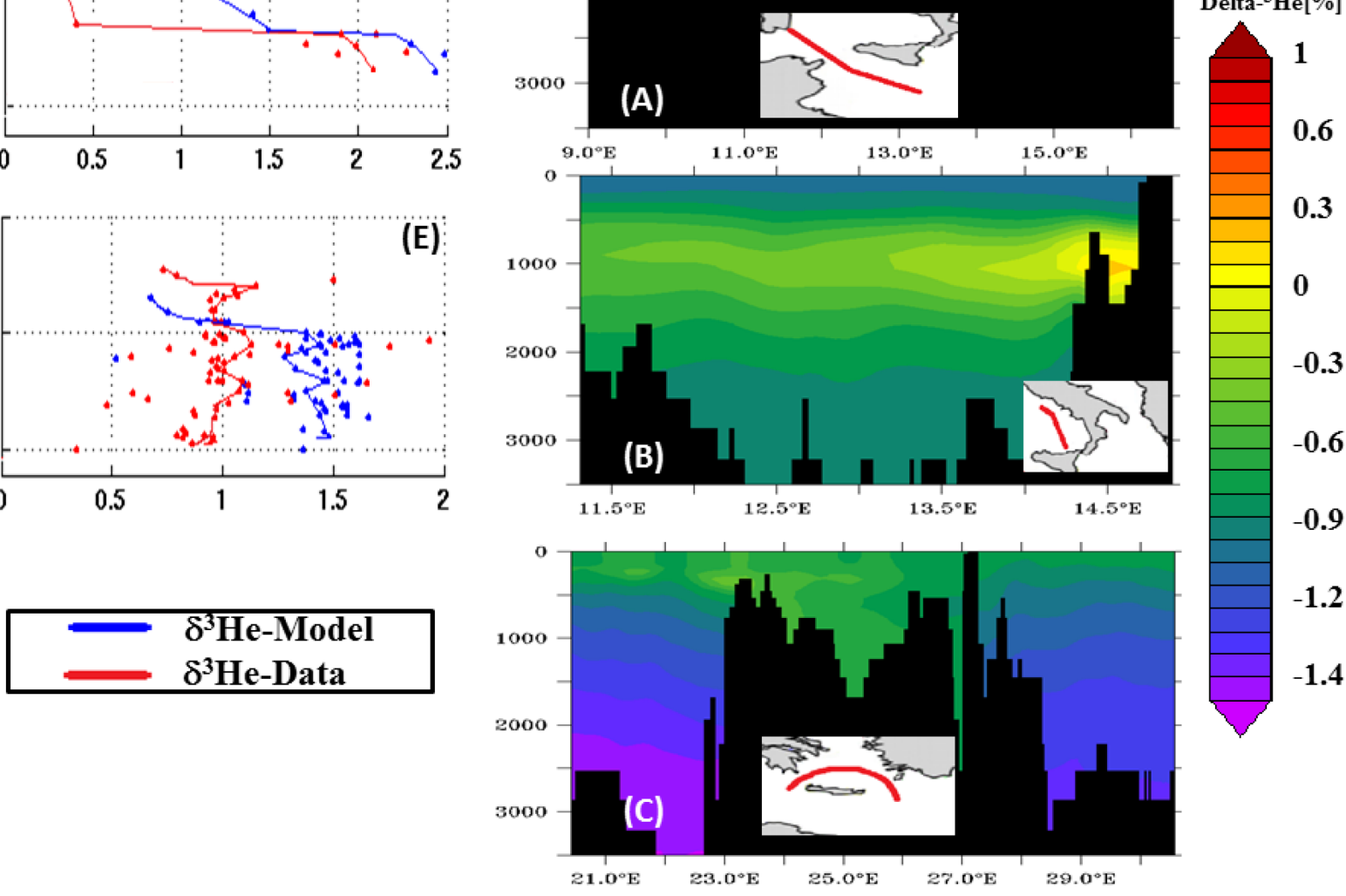

Figure 5. Mantle+atmospheric $\delta^{3} \mathrm{He}(\%)$ model-data comparison in (a) the Sicily Channel, (b) Tyrrhenian sub-basin, and (c) Aegean subbasin. (d) Vertical profiles of $\delta^{3} \mathrm{He}$ (above the atmospheric background of $-1.6 \%$ ) at $12.5^{\circ} \mathrm{E}$ in the Sicily Channel; model results are in blue; red indicates in situ data (Fourré and Jean-Baptiste, unpublished results). (e): same as (d) for the Tyrrhenian sub-basin. The data are from Lupton et al. (2011). The few stations located right above a plume in Lupton et al. (2011) have been discarded because they cannot be compared to model results which are averaged over the volume of the model cell $\left(\sim 20 \mathrm{~km}^{3}\right)$. There are no data for the Aegean basin.

\subsection{Total helium-3 distribution}

The Mediterranean Sea is characterized by coexisting terrigenic and tritiugenic helium throughout its subsurface waters. Figure 7 presents a model-data comparison of the simulated total $\delta^{3} \mathrm{He}$ (sum of terrigenic, tritiugenic and atmospheric helium) in 1987, along the W-E Emed transect corresponding to the Meteor 5 cruise (1987). The tritiugenic component in 1987 is taken from (Ayache et al., 2015). Figure 7 exhibits a $\delta^{3} \mathrm{He}$ maximum at a few hundred metres depth, hinting at the presence of tritiugenic ${ }^{3} \mathrm{He}$ produced by the radioactive decay of anthropogenic bomb tritium. Further down $\delta^{3} \mathrm{He}$ values decrease and, in the Levantine basin, even dropping below the value for solubility equilibrium with the atmosphere $(\sim-1.6 \%)$. This represents the signature of crustal helium in the deep Mediterranean waters.
The model correctly reproduces the $\delta^{3} \mathrm{He}$ maximum of the intermediate waters, with values similar to observations, except in the eastern part of the section, where it tends to be overestimated. Deeper, we have a realistic simulation of the helium signal in the Levantine sub-basin (Fig. 7b) with $\delta^{3} \mathrm{He}$ around $-5 \%$, which is in good agreement with observations made during Meteor cruise M5, with only $10 \%$ of difference between the simulated $\delta^{3} \mathrm{He}$ mean vertical profile and in situ data below $2000 \mathrm{~m}$ depth (Fig. 7b). Again, one can clearly see that the shortcoming associated with the too-weak EMDW formation in the Adriatic sub-basin leads to excessively negative $\delta^{3} \mathrm{He}$ values at depth: the model tends to underestimate the $\delta^{3} \mathrm{He}$ levels in the deep water by more than $60 \%$ compared to observations below $2000 \mathrm{~m}$ depth (Fig. 7c).

Comparison of the tritiugenic and mantle $\delta^{3} \mathrm{He}$ signatures, which occur at similar depths in the Mediterranean Sea, shows that tritiugenic ${ }^{3} \mathrm{He}$ clearly dominates over mantle 


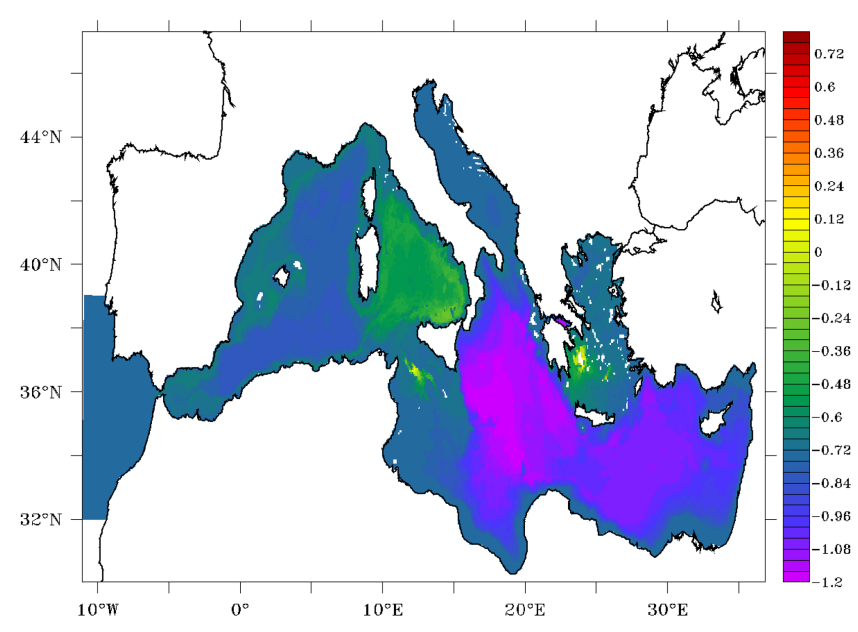

Figure 6. Horizontal distribution of $\delta^{3} \mathrm{He}_{\text {mantle }}(\%)$ (vertically averaged) across the Mediterranean Sea.

${ }^{3} \mathrm{He}$. This finding agrees with those of Roether and Lupton (2011) for the Tyrrhenean basin; they concluded that most of the helium-3 excess is tritiugenic.

\section{Discussion}

We have presented the first simulation of the terrigenic helium isotope distribution in the Mediterranean Sea, using a high-resolution model (NEMO-MED12). For this simulation we built a source function for terrigenic (crustal and mantle) helium isotopes obtained by simple scaling of published flux estimates (Tables 1 and 2). For crustal helium, our helium flux equal to $1.6 \times 10^{-7}{ }^{4} \mathrm{He} \mathrm{mol} \mathrm{m}{ }^{-2} \mathrm{yr}^{-1}$ generates a satisfying agreement with the data in the Levantine basin, where the tritium $/{ }^{3} \mathrm{He}$ simulations of Ayache et al. (2015) have shown that modelled ventilation of the deep waters is correct. This flux represents only $10 \%$ of the previous estimate by Roether et al. (1998) for the eastern Mediterranean $\left(1.6 \times 10^{-6}{ }^{4} \mathrm{He} \mathrm{mol} \mathrm{m}-2 \mathrm{yr}^{-1}\right)$, based on a box model where the thermohaline circulation of the eastern Mediterranean is represented by a deep-water reservoir (> $1000 \mathrm{~m}$ depth) and two intermediate water cells.

The tritium $/{ }^{3} \mathrm{He}$ (Ayache et al., 2015) and CFC (Palmiéri et al., 2015) simulations have shown that the model adequately represents ventilation of near-surface and intermediate waters but globally underestimates the ventilation rate of the Mediterranean deep waters, particularly in the Ionian sub-basin, where the deep-water ventilation associated with the Adriatic Deep Water (AdDW) is too shallow in the simulations compared to observations. This mismatch is likely due to an overestimation of the freshwater flux (precipitation-evaporation and runoff) into the Adriatic subbasin. Taking into account this model deficiency, our estimate must be considered as a lower limit of the crustal helium flux into the Mediterranean basin.
For mantle helium, our simple parameterization produces realistic simulated $\delta^{3} \mathrm{He}$ values that are in agreement with in situ measurements, thus supporting our scaling approach. This study provides a useful constraint on the magnitude of the hydrothermal helium-3 fluxes in the Mediterranean Sea (Table 1) that is of interest because this flux can now be used to estimate the hydrothermal flux of other chemical species. Hydrothermal venting produces plumes in the ocean that are highly enriched in a variety of chemical species. Hydrothermal activity impacts the global cycling of elements in the ocean (Elderfield and Schultz, 1996), including economically valuable minerals such as rare-earth elements (REE) which are deposited in deep sea sediments. These minerals are crucial in the manufacture of novel electronic equipment and green-energy technologies (Kato et al., 2011). Hydrothermal chemical elements such as iron also impact biological cycles and eventually the carbon cycle and climate (Tagliabue et al., 2010). Our simulations show that highresolution oceanic models coupled with measurements of conservative hydrothermal tracers such as helium isotopes can be useful tools to study the environmental impact of hydrothermal activity in a variety of marine environments and at a variety of scales. Beyond the case of hydrothermal activity, it also shows that high-resolution ocean circulation models such as NEMO-MED 12 are well suited for the study of the evolution of quasi-enclosed basins such as the Mediterranean Sea that are under increasing anthropogenic pressure.

The global inventory of helium isotopes in the Mediterranean Sea based on our simulations indicates the relative contribution of each source of the tracer (Table 3). Besides atmospheric helium, which is the main source of both ${ }^{3} \mathrm{He}$ and ${ }^{4} \mathrm{He}$, it shows that tritiugenic ${ }^{3} \mathrm{He}$ and crustal ${ }^{4} \mathrm{He}$ are the main contributors to ${ }^{3} \mathrm{He}$ and ${ }^{4} \mathrm{He}$ excesses over solubility equilibrium. Therefore, in contrast to the world's oceans, where mantle helium dominates over other terrigenic and tritiugenic components, the mantle helium component linked to the submarine volcanic/hydrothermal activity is relatively small compared to the other sources of helium in the Mediterranean Sea. This is due to the cumulated effects of (1) the relatively shallow depths of hydrothermal injections in the Mediterranean $(<1000 \mathrm{~m})$ compared to the mid-ocean ridges (MORs), mostly in the range $2000-4000 \mathrm{~m}$ that favour a more rapid degassing through the air-sea interface; (2) lower helium flux from arc volcanism (20\%) compared to MOR volcanism (Torgersen, 1989; Hilton et al., 2002); and (3) high crustal-He flux in the Mediterranean basin due to its intra-continental nature (i.e. with a continental-type crust and high sediment load of continental origin). However, despite its minor contribution to the global helium-3 budget, the hydrothermal component remains identifiable due to its elevated isotopic signature. 

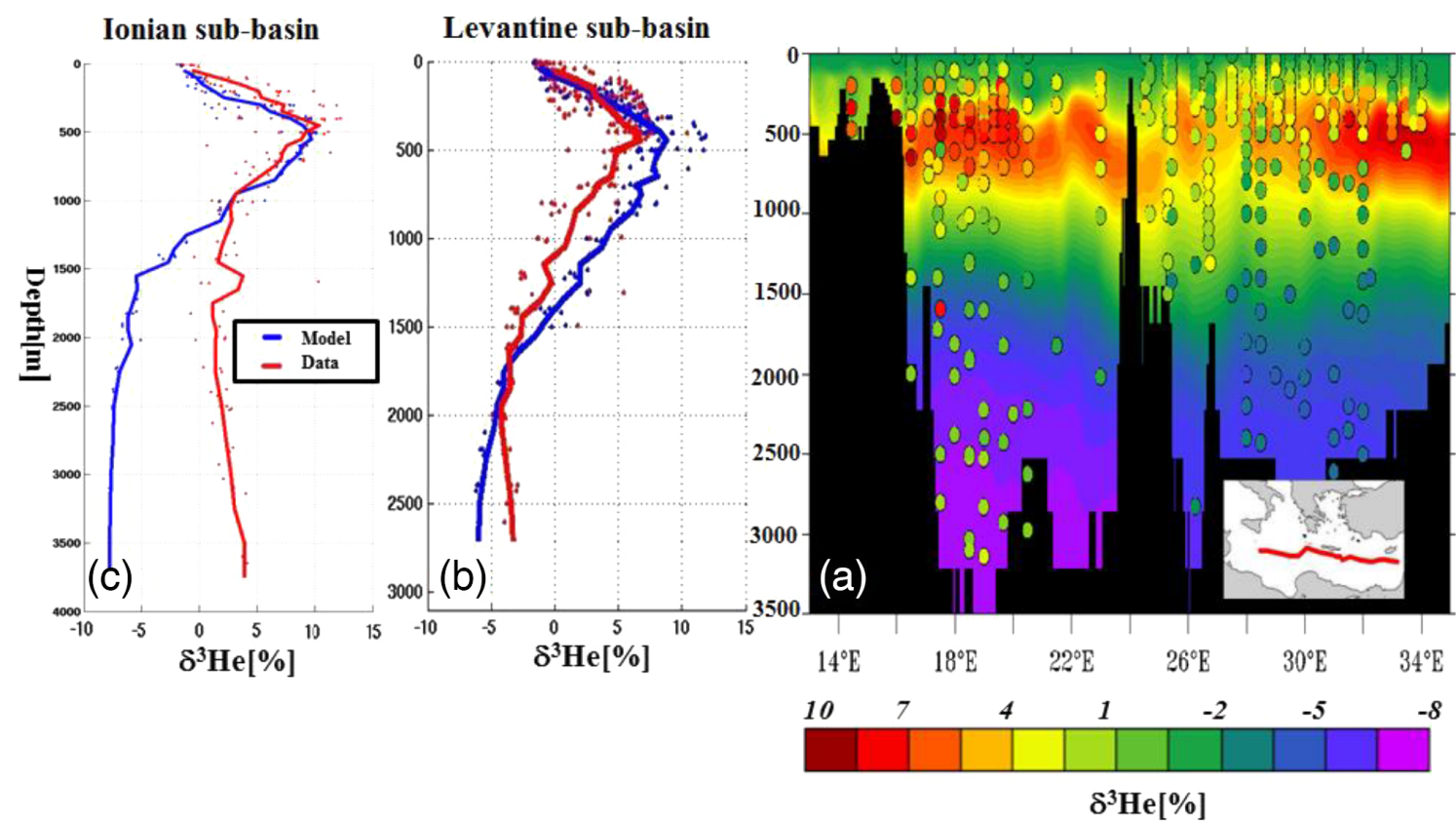

Figure 7. Total $\delta^{3} \mathrm{He}$ (sum of terrigenic, tritiugenic and atmospheric helium) model-data comparison along the Meteor M5 (September 1987) section. (a) Colour-filled contours indicate simulated $\delta^{3} \mathrm{He}(\%)$, whereas colour-filled dots represent in situ observations. (b) and (c): comparison of average vertical profiles for the Levantine and Ionian sub-basins, respectively; model results are in blue; red indicates in situ data.

Table 3. Helium inventory (in mole) in the Mediterranean Sea.

\begin{tabular}{lrrrr}
\hline & Helium-3 & $\%$ (terrigenic) & Helium-4 & $\%$ (terrigenic) \\
\hline Mantle & 5 & 0.8 & $6.04 \mathrm{e} 05$ & 0.3 \\
Crust & 18 & 2.9 & $2.18 \mathrm{e} 08$ & 99.3 \\
Tritugenic (1987) & 599 & 96.3 & 0 & 0 \\
Atmospheric & 9070 & & $6.67 \mathrm{e} 09$ & \\
Total & 9692 & & $6.89 \mathrm{e} 09$ & \\
\hline
\end{tabular}

\section{Conclusions}

The terrigenic helium isotope distribution was simulated for the first time in the whole Mediterranean Sea, using a highresolution model (NEMO-MED12) at one-twelfth of a degree horizontal resolution $(6-8 \mathrm{~km})$. The parameterization of the helium injection at the seafloor led to results of sufficient quality to allow us to put valuable constraints on the crustal and mantle helium fluxes. Helium simulations also confirmed some shortcomings of the model dynamics in representing the deep ventilation of the Ionian basin, already pinpointed by recent transient tracer studies. In spite of these limitations and of the limited data set at our disposal for model-data comparison, our work puts additional constraints on the origin of the helium isotopic signature in the Mediterranean Sea. The simulation of this tracer and its comparison with observations provide a new and additional technique for assessing and improving the NEMO-MED12 dynamical regional model. This is essential if we are to improve our ability to predict the future evolution of the Mediterranean Sea under the increasing anthropogenic pressure that it is suffering (Drobinski et al., 2012). It also offers new opportunities to study chemical element cycling, particularly in the context of the increasing amount of data that will result from the international GEOTRACES effort (GEOTRACE, 2007).

Acknowledgements. We are grateful to M. Hecht (topical editor) for his careful reading of the manuscript. We thank W. Roether and the anonymous referee for their constructive comments and suggestions. We thank J. Palmieri for his help with technical aspects, and Y. Donnadieu for computing support.

Edited by: M. Hecht 


\section{References}

Allard, P.: Global emissions of helium-3 by subaerial volcanism, Geophys. Res. Lett., 19, 1479-1481, 1992a.

Allard, P.: Correction to "Global emissions of helium-3 by subaerial volcanism", Geophys. Res. Lett., 19, 2103-2103, 1992b.

Andrie, C. and Merlivat, L.: Tritium in the western Mediterranean Sea during 1981 Phycemed cruise, Deep-Sea Res. Pt. A, 35, $247-$ 267, 1988.

Antonov, J. I., Locarnini, R. A., Boyer, T. P., Mishonov, A. V., and Garcia, H. E.: World Ocean Atlas 2005, Salinity, edited by: Levitus, S., NOAA Atlas NESDIS 62, US Government Printing Office, Washington, DC, 2, 182 pp., 2006.

Ayache, M., Dutay, J.-C., Jean-Baptiste, P., Beranger, K., Arsouze, T., Beuvier, J., Palmieri, J., Le-vu, B., and Roether, W.: Modelling of the anthropogenic tritium transient and its decay product helium-3 in the Mediterranean Sea using a high-resolution regional model, Ocean Sci., 11, 323-342, doi:10.5194/os-11-3232015, 2015.

Ballentine, C. J. and Burnard, P. G.: Production, Release and Transport of Noble Gases in the Continental Crust, Rev. Mineral. Geochem., 47, 481-538, 2002.

Beuvier, J., Béranger, K., Lebeaupin Brossier, C., Somot, S., Sevault, F., Drillet, Y., Bourdallé-Badie, R., Ferry, N., and Lyard, F.: Spreading of the Western Mediterranean Deep Water after winter 2005: Time scales and deep cyclone transport, J. Geophys. Res., 117, C07022, doi:10.1029/2011JC007679, 2012a.

Beuvier, J., Lebeaupin Brossier, C., Béranger, K., Arsouze, T., Bourdallé-Badie, R., Deltel, C., Drillet, Y., Drobinski, P., Lyard, F., Ferry, N., Sevault, F., , and Somot, S.: MED12, Oceanic component for the modelling of the regional Mediterranean Earth System, Merc. Oc. Quart. Newslett., 46, 60-66, 2012b.

Bianchi, D., Sarmiento, J. L., Gnanadesikan, A., Key, R. M., Schlosser, P., and Newton, R.: Low helium flux from the mantle inferred from simulations of oceanic helium isotope data, Earth Planet. Sci. Lett., 297, 379-386, 2010.

Capaccioni, B., Tassi, F., Vaselli, O., Tedesco, D., and Poreda, R.: Submarine gas burst at Panarea Island (southern Italy) on 3 November 2002: A magmatic versus hydrothermal episode, J. Geophys. Res., 112, B05201, doi:10.1029/2006JB004359, 2007.

Capasso, G., Carapezza, M. L., Federico, C., Inguaggiato, S., and Rizzo, A.: Geochemical monitoring of the 2002-2003 eruption at Stromboli volcano (Italy): precursory changes in the carbon and helium isotopic composition of fumarole gases and thermal waters, Bull. Volcanol., 68, 118-134, 2005.

Chaduteau, C., Jean-Baptiste, P., Fourré, E., Charlou, J.-L., and Donval, J.-P.: Helium transport in sediment pore fluids of the Congo-Angola margin, Geochem. Geophys. Geosyst., 10, 1-12, doi:10.1029/2007GC001897, 2009.

Charlou, J., Donval, J., Zitter, T., Roy, N., Jean-Baptiste, P., Foucher, J., and Woodside, J.: Evidence of methane venting and geochemistry of brines on mud volcanoes of the eastern Mediterranean Sea, Deep-Sea Res. Pt. I, 50, 941-958, 2003.

Clarke, W., Jenkins, W., and Top, Z.: Determination of tritium by mass spectrometric measurement of ${ }^{3} \mathrm{He}$, Int. J. Appl. Radiat. Isotopes, 27, 515-522, 1976.

Clarke, W. B., Beg, M. A., and Craig, H.: Excess helium 3 at the North Pacific Geosecs Station, J. Geophys. Res., 75, 7676-7678, 1970.
Craig, H. and Lupton, J. E.: Helium-3 and mantle volatiles in the ocean and the oceanic crust, Oc. Lithos., 7, 391-428, 1981.

Craig, H. and Weiss, R. F.: Dissolved gas saturation anomalies and excess helium in the ocean, Earth Planet. Sci. Lett., 10, 289-296, 1971.

D’Alessandro, W., De Gregorio, S., Dongarrà, G., Gurrieri, S., Parello, F., and Parisi, B.: Chemical and isotopic characterization of the gases of Mount Etna (Italy), J. Volcanol. Geotherm. Res., 78, 65-76, 1997.

Dando, P., Stüben, D., and Varnavas, S.: Hydrothermalism in the Mediterranean Sea, Prog. Oceanogr., 44, 333-367, 1999.

Drobinski, P., Anav, A., Lebeaupin Brossier, C., Samson, G., Stéfanon, M., Bastin, S., Baklouti, M., Béranger, K., Beuvier, J., Bourdallé-Badie, R., Coquart, L., D’Andrea, F., de NobletDucoudré, N., Diaz, F., Dutay, J.-C., Ethe, C., Foujols, M.A., Khvorostyanov, D., Madec, G., Mancip, M., Masson, S., Menut, L., Palmieri, J., Polcher, J., Turquety, S., Valcke, S., and Viovy, N.: Model of the Regional Coupled Earth system (MORCE): Application to process and climate studies in vulnerable regions, Env. Modell. Software, 35, 1-18, doi:10.1016/j.envsoft.2012.01.017, 2012.

Dutay, J.-C., Bullister, J., Doney, S., Orr, J., Najjar, R., Caldeira, K., Campin, J.-M., Drange, H., Follows, M., Gao, Y., Gruber, N., Hecht, M., Ishida, A., Joos, F., Lindsay, K., Madec, G., MaierReimer, E., Marshall, J., Matear, R., Monfray, P., Mouchet, A., Plattner, G.-K., Sarmiento, J., Schlitzer, R., Slater, R., Totterdell, I., Weirig, M.-F., Yamanaka, Y., and Yool, A.: Evaluation of ocean model ventilation with CFC-11: comparison of 13 global ocean models, Ocean Modell., 4, 89-120, 2002.

Dutay, J.-C., Jean-Baptiste, P., Campin, J.-M., Ishida, A., MaierReimer, E., Matear, R., Mouchet, A., Totterdell, I., Yamanaka, Y., Rodgers, K., Madec, G., and Orr, J.: Evaluation of OCMIP2 ocean models' deep circulation with mantle helium-3, J. Mar. Syst., 48, 15-36, 2004.

Dutay, J. C., Emile-Geay, J., Iudicone, D., Jean-Baptiste, P., Madec, G., and Carouge, C.: Helium isotopic constraints on simulated ocean circulations: Implications for abyssal theories, Environ. Fluid Mechan., 10, 257-273, 2010.

Elderfield, H. and Schultz, A.: Mid-Ocean Ridge Hydrothermal Fluxes and the Chemical Composition of the Ocean, Ann. Rev. Earth Planet. Sci., 24, 191-224, 1996.

England, M. H.: The age of water and ventilation timescales in a global ocean model, J. Phys. Oceanogr., 25, 2756-2777, 1995.

Farley, K. A., Maier-Reimer, E., Schlosser, P., and Broecker, W. S.: Constraints on mantle 3 He fluxes and deep-sea circulation from an oceanic general circulation model, J. Geophys. Res., 100, 3829, doi:10.1029/94JB02913, 1995.

Ferry, N., Parent, L., Garric, G., Barnier, B., and Jourdain, N. C.: Mercator Global Eddy Permitting Ocean Reanalysis GLORYS1V1: Description and Results, Mercat. Oc. Quart. Newslett., 36, 15-28, 2010.

Fiebig, J., Chiodini, G., Caliro, S., Rizzo, A., Spangenberg, J., and Hunziker, J. C.: Chemical and isotopic equilibrium between $\mathrm{CO}_{2}$ and $\mathrm{CH}_{4}$ in fumarolic gas discharges: Generation of $\mathrm{CH}_{4}$ in arc magmatic-hydrothermal systems, Geochim. Cosmochim. Ac., 68, 2321-2334, 2004.

Fourré, E., Allard, P., Jean-Baptiste, P., Cellura, D., and Parello, F.: $\mathrm{H} 3 \mathrm{e} / \mathrm{H} 4 \mathrm{e}$ Ratio in Olivines from Linosa, Ustica, and Pantelleria Islands (Southern Italy), J. Geol. Res., 2012, 1-8, 2012. 
GEOTRACE: GEOTRACES - An international study of the global marine biogeochemical cycles of trace elements and their isotopes, Chemie der Erde - Geochemistry, 67, 85-131, 2007.

Goodman, P. J.: The Role of North Atlantic Deep Water Formation in an OGCM's Ventilation and Thermohaline Circulation, J. Phys. Oceanogr., 28, 1759-1785, 1998.

Graham, D. W.: Noble Gas Isotope Geochemistry of Mid-Ocean Ridge and Ocean Island Basalts: Characterization of Mantle Source Reservoirs, Rev. Mineral. Geochem., 47, 247-317, 2002.

Herrmann, M., Sevault, F., Beuvier, J., and Somot, S.: What induced the exceptional 2005 convection event in the northwestern Mediterranean basin? Answers from a modeling study, J. Geophys. Res., 115, C12051, doi:10.1029/2010JC006162, 2010.

Herrmann, M. J. and Somot, S.: Relevance of ERA40 dynamical downscaling for modeling deep convection in the Mediterranean Sea, Geophys. Res. Lett., 35, L04607, doi:10.1029/2007GL032442, 2008.

Hilton, D. R., Fischer, T. P., and Marty, B.: Noble Gases and Volatile Recycling at Subduction Zones, Rev. Mineral. Geochem., 47, 319-370, doi:10.2138/rmg.2002.47.9, 2002.

Jähne, B., Heinz, G., and Dietrich, W.: Measurement of the diffusion coefficients of sparingly soluble gases in water, J. Geophys. Res., 92, 10767, doi:10.1029/JC092iC10p10767, 1987a.

Jähne, B., Münnich, K. O., Bösinger, R., Dutzi, A., Huber, W., and Libner, P.: On the parameters influencing air-water gas exchange, J. Geophys. Res., 92, 1937, doi:10.1029/JC092iC02p01937, $1987 b$.

Jamous, D., Mémery, L., Andrié, C., Jean-Baptiste, P., and Merlivat, L.: The distribution of helium 3 in the deep western and southern Indian Ocean, J. Geophys. Res., 97, 2243, doi:10.1029/91JC02062, 1992.

Jean-Baptiste, P., Charlou, J., Stievenard, M., Donval, J., Bougault, H., and Mevel, C.: Helium and methane measurements in hydrothermal fluids from the mid-Atlantic ridge: The Snake Pit site at $23^{\circ}$ N, Earth Planet. Sci. Lett., 106, 17-28, doi:10.1016/0012821X(91)90060-U, 1991a.

Jean-Baptiste, P., Charlou, J. L., Stievenard, M., Donval, J., Bougault, H., and Mevel, C.: Helium and methane measurements in hydrothermal fluids from the Mid Atlantic Ridge: the SNAKE PIT site at $23^{\circ} \mathrm{N}$, Earth Planet. Sci. Lett., 106, 17-28, $1991 \mathrm{~b}$.

Jean-Baptiste, P., Mantisi, F., Memery, L., and Jamous, D.: Helium3 and CFC in the Southern Ocean: tracers of water masses, Mar. Chem., 35, 137-150, 1992.

Jean-Baptiste, P., Dapoigny, A., Stievenard, M., Charlou, J. L., Fouquet, Y., Donval, J. P., and Auzende, J. M.: Helium and oxygen isotope analyses of hydrothermal fluids from the East Pacific Rise between $17^{\circ} \mathrm{S}$ and $19^{\circ} \mathrm{S}$, Geo-Mar. Lett., 17, 213-219, 1997.

Jean-Baptiste, P., Fourré, E., Metzl, N., Ternon, J., and Poisson, A.: Red Sea deep water circulation and ventilation rate deduced from the 3He and 14C tracer fields, J. Mar. Syst., 48, 37-50, 2004.

Jenkins, D. J., Wolever, T. M., Leeds, A. R., Gassull, M. A., Haisman, P., Dilawari, J., Goff, D. V., Metz, G. L., and Alberti, K. G.: Dietary fibres, fibre analogues, and glucose tolerance: importance of viscosity., Tech. Rep., 6124, doi:10.1136/bmj.1.6124.1392, 1978.

Jenkins, W. and Clarke, W.: The distribution of $3 \mathrm{He}$ in the western Atlantic ocean, Deep-Sea Res. Oceanogr. Abstr., 23, 481-494, 1976.
Jenkins, W. J.: Tritium-helium dating in the sargasso sea: a measurement of oxygen utilization rates., Science (New York, NY), 196, 291-2, 1977.

Jenkins, W. J.: The use of Anthropogenic Tritium and He-3 to Study Sub-Tropical Gyre Ventilation and Circulation, Philos. T. R. Soc. A, 325, $43-61,1988$.

Kato, Y., Fujinaga, K., Nakamura, K., Takaya, Y., Kitamura, K., Ohta, J., Toda, R., Nakashima, T., and Iwamori, H.: Deep-sea mud in the Pacific Ocean as a potential resource for rare-earth elements, Nature Geosci., 4, 535-539, 2011.

Kipfer, R., Aeschbach-Hertig, W., Peeters, F., and Stute, M.: Noble Gases in Lakes and Ground Waters, Rev. Mineral. Geochem., 47, 615-700, 2002.

Lebeaupin Brossier, C., Béranger, K., Deltel, C., and Drobinski, P.: The Mediterranean response to different space-time resolution atmospheric forcings using perpetual mode sensitivity simulations, Oc. Modell., 36, 1-25, 2011.

Locarnini, R. A., Mishonov, A. V., Antonov, J. I., Boyer, T. P., and Garcia, H. E.: World Ocean Atlas 2005, Volume 1: Temperature, edited by: Levitus, S., NOAA Atlas NESDIS 61, US Government Printing Office, Washington, DC, 182 pp., 2006.

Ludwig, W., Dumont, E., Meybeck, M., and Heussner, S.: River discharges of water and nutrients to the Mediterranean and Black Sea: Major drivers for ecosystem changes during past and future decades?, Prog. Oceanogr., 80, 199-217, 2009.

Lupton, J.: Hydrothermal helium plumes in the Pacific Ocean, J. Geophys. Res., 103, 15853, doi:10.1029/98JC00146, 1998.

Lupton, J., de Ronde, C., Sprovieri, M., Baker, E. T., Bruno, P. P., Italiano, F., Walker, S., Faure, K., Leybourne, M., Britten, K., and Greene, R.: Active hydrothermal discharge on the submarine Aeolian Arc, J. Geophys. Res., 116, B02102, doi:10.1029/2010JB007738, 2011.

Lupton, J. E.: Helium-3 in the Guaymas Basin: Evidence for injection of mantle volatiles in the Gulf of California, J. Geophys. Res., 84, 7446, doi:10.1029/JB084iB13p07446, 1979.

Lupton, J. E.: A Far-Field Hydrothermal Plume from Loihi Seamount, Science, 272, 976-979, 1996.

Lupton, J. E., Weiss, R. F., and Craig, H.: Mantle helium in the Red Sea brines, Nature, 266, 244-246, 1977a.

Lupton, J. E., Weiss, R. F., and Craig, H.: Mantle helium in hydrothermal plumes in the Galapagos Rift, Nature, 267, 603-604, $1977 b$.

Madec, G. and NEMO-Team.: Note du Pôle de modélisation, Institut Pierre-Simon Laplace (IPSL), France, NEMO Ocean Engine, 27, ISSN N1288-1619, 2008.

Martelli, M., Caracausi, A., Paonita, A., and Rizzo, A.: Geochemical variations of air-free crater fumaroles at Mt Etna: New inferences for forecasting shallow volcanic activity, Geophys. Res. Lett., 35, L21302, doi:10.1029/2008GL035118, 2008.

MEDAR-MedAtlas-group: Medar-Medatlas Protocol (Version 3) Part I: Exchange Format and Quality Checks for Observed Profiles, P. Rap. Int. IFREMER/TMSI/IDM/SIS002-006, 50, 2002.

Palmiéri, J., Orr, J. C., Dutay, J.-C., Béranger, K., Schneider, A., Beuvier, J., and Somot, S.: Simulated anthropogenic $\mathrm{CO}_{2}$ storage and acidification of the Mediterranean Sea, Biogeosciences, 12, 781-802, doi:10.5194/bg-12-781-2015, 2015.

Parello, F., Allard, P., D'Alessandro, W., Federico, C., JeanBaptiste, P., and Catani, O.: Isotope geochemistry of Pantelleria volcanic fluids, Sicily Channel rift: a mantle volatile end-member 
for volcanism in southern Europe, Earth Planet. Sci. Lett., 180, 325-339, 2000.

Rhein, M., Send, U., Klein, B., and Krahmann, G.: Interbasin deep water exchange in the western Mediterranean. J. Geophys. Res., 104, 23495-23508, 1999.

Rixen, M., Beckers, J. M., Levitus, S., Antonov, J., Boyer, T., Maillard, C., Fichaut, M., Balopoulos, E., Iona, S., Dooley, H., Garcia, M. J., Manca, B., Giorgetti, A., Manzella, G., Mikhailov, N., Pinardi, N., and Zavatarelli, M.: The Western Mediterranean Deep Water: A proxy for climate change, Geophys. Res. Lett., 32, 1-4, 2005.

Roether, W. and Lupton, J. E.: Tracers confirm downward mixing of Tyrrhenian Sea upper waters associated with the Eastern Mediterranean Transient, Ocean Sci., 7, 91-99, doi:10.5194/os7-91-2011, 2011.

Roether, W., Roussenov, V. M., and Well, R.: A tracer study of the thermohaline circulation of the eastern Mediterranean, Oc. Proc. Clim. Dynam., 371-394, 1994.

Roether, W., Manca, B. B., Klein, B., Bregant, D., Georgopoulos, D., Beitzel, V., Kovacevic, V., and Luchetta, A.: Recent Changes in Eastern Mediterranean Deep Waters, Science, 271, 333-335, 1996.

Roether, W., Well, R., Putzka, A., and Rüth, C.: Component separation of oceanic helium, J. Geophys. Res., 103, 27931-27946, doi:10.1029/98JC02234, 1998.

Roether, W., Well, R., Putzka, A., and Rüth, C.: Correction to "Component separation of oceanic helium" by Wolfgang Roether, Roland Well, Alfred Putzka, and Christine Rüth, J. Geophys. Res., 106, 4679-4679, 2001.

Roether, W., Klein, B., Manca, B. B., Theocharis, A., and Kioroglou, S.: Transient Eastern Mediterranean deep waters in response to the massive dense-water output of the Aegean Sea in the 1990s, Prog. Oceanogr., 74, 540-571, 2007.

Roether, W., Jean-Baptiste, P., Fourré, E., and Sültenfuß, J.: The transient distributions of nuclear weapon-generated tritium and its decay product ${ }^{3} \mathrm{He}$ in the Mediterranean Sea, 1952-2011, and their oceanographic potential, Ocean Sci., 9, 837-854, doi:10.5194/os-9-837-2013, 2013.

Roether, W., Klein, B., and Hainbucher, D.: The Eastern Mediterranean Transient: Evidence for Similar, Am. Geophys. Union, 12, 75-83, 2014.

Rüth, C., Well, R., and Roether, W.: Primordial in South Atlantic deep waters from sources on the Mid-Atlantic Ridge, Deep-Sea Res. Pt. I, 47, 1059-1075, 2000.

Sano, T., Hataya, T., Terai, Y., and Shikata, E.: Hop stunt viroid strains from dapple fruit disease of plum and peach in Japan, J. Gen. Virol., 70, 1311-9, 1989.

Sano, Y. and Wakita, H.: Geographical distribution of ${ }^{3} \mathrm{He} /{ }^{4} \mathrm{He}$ ratios in Japan: Implications for arc tectonics and incipient magmatism, J. Geophys. Res., 90, 8729, doi:10.1029/JB090iB10p08729, 1985.

Sano, Y., Wakita, H., Ohsumi, T., and Kusakabe, M.: Helium isotope evidence for magmatic gases in Lake Nyos, Cameroon, Geophys. Res. Lett., 14, 1039-1041, 1987.

Schlosser, P. and Winckler, G.: Noble Gases in Ocean Waters and Sediments, Rev. Mineral. Geochem., 47, 701-730, 2002.

Schlosser, P., Bullister, J. L., and Bayer, R.: Studies of deep water formation and circulation in the Weddell Sea using natural and anthropogenic tracers, Mar. Chem., 35, 97-122, 1991.
Shimizu, A., Sumino, H., Nagao, K., Notsu, K., and Mitropoulos, P.: Variation in noble gas isotopic composition of gas samples from the Aegean arc, Greece, J. Volcanol. Geotherm. Res., 140, 321-339, 2005.

Soto-Navarro, J., Somot, S., Sevault, F., Beuvier, J., Béranger, K., Criado-Aldeanueva, F., and García-Lafuente, J.: Evaluation of regional ocean circulation models for the Mediterranean Sea at the Strait of Gibraltar : volume transport and thermohaline properties of the outflow, Clim. Dynam., 44, 1277-1292, doi:10.1007/s00382-014-2179-4, 2014.

Srinivasan, A., Top, Z., Schlosser, P., Hohmann, R., Iskandarani, M., Olson, D. B., Lupton, J. E., and Jenkins, W. J.: Mantle 3He distribution and deep circulation in the Indian Ocean, https: //darchive.mblwhoilibrary.org/handle/1912/3711, 2004.

Tagliabue, A., Bopp, L., Dutay, J.-C., Bowie, A. R., Chever, F., Jean-Baptiste, P., Bucciarelli, E., Lannuzel, D., Remenyi, T., Sarthou, G., Aumont, O., Gehlen, M., and Jeandel, C.: Hydrothermal contribution to the oceanic dissolved iron inventory, Nat. Geosci., 3, 252-256, 2010.

Taylor, S. and McLennan, S.: The Continental Crust, Its composition and evolution, an examination of the geochemical record preserved in sedimentary rocks, Blackwell, Oxford, 312 pp., 1985.

Tedesco, D. and Scarsi, P.: Intensive gas sampling of noble gases and carbon at Vulcano Island (southern Italy), J. Geophys. Res., 104, 10499, doi:10.1029/1998JB900066, 1999.

Tedesco, D., Miele, G., Sano, Y., and Toutain, J. P.: Helium isotopic ratio in Vulcano island fumaroles: temporal variations in shallow level mixing and deep magmatic supply, J. Volcanol. Geotherm. Res., 64, 117-128, 1995.

Top, Z. and Clarke, W. B.: Helium, neon, and tritium in the Black Sea, J. Mar. Res., 41, 1-17, 1983.

Top, Z., Östlund, G., Pope, L., and Grall, C.: Helium isotopes, neon and tritium in the Black Sea: A comparison with the 1975 observations, Deep-Sea Res. Pt. A, 38, S747-S759, 1991.

Torgersen, T.: Terrestrial helium degassing fluxes and the atmospheric helium budget: Implications with respect to the degassing processes of continental crust, Chem. Geol., 79, 1-14, 1989.

Torgersen, T.: Continental degassing flux of $4 \mathrm{He}$ and its variability, Geochem. Geophys. Geosyst., 11, Q06002, doi:10.1029/2009GC002930, 2010.

Vörösmarty, C. J., Fekete, B. M., and Tucker, B. A.: Global River Discharge Database (RivDIS V1.0), International Hydrological Program, Global Hydrological Archive and Analysis Systems, UNESCO, Paris, 1996.

Wanninkhof, R.: Relationship between wind speed and gas exchange over the ocean, J. Geophys. Res., 97, 7373, doi:10.1029/92JC00188, 1992.

Weiss, R. F.: Solubility of helium and neon in water and seawater, J. Chem. Engin. Data, 16, 235-241, 1971.

Well, R., Lupton, J., and Roether, W.: Crustal helium in deep Pacific waters, J. Geophys. Res., 106, 14165, doi:10.1029/1999JC000279, 2001.

Winckler, G., Suess, E., Wallmann, K., de Lange, G. J., Westbrook, G. K., and Bayer, R.: Excess helium and argon of radiogenic origin in Mediterranean brine basins, Earth Planet. Sci. Lett., 151, 225-231, 1997. 